\title{
GOOD COOPERATIVES GOVERNANCE AND PERFORMANCE IN BANYUMAS REGION
}

\author{
Feriani Budiyah ${ }^{1}$, Eko Suyono ${ }^{2}$ \\ ${ }^{1}$ Faculty of Social, Economics and Humanities,Nahdlatul Ulama University, Purwokerto \\ ${ }^{2}$ Faculty of Economics and Business, Jenderal Soedirman University \\ Email: f.budiyah@unupurwokerto.ac.id
}

\begin{abstract}
This study aims to analyze the influence of good cooperative governance (i.e., transparency, accountability, responsibility, independence, and fairness) on cooperative performance. By using a purposive sampling method this study ended-up with 32 cooperatives in Banyumas as samples with the questionnaires were distributed during August 7-13, 2015. The findings from OLS regression show that all governance variables (i.e., transparency, accountability, responsibility, independence, and fairness) influence positively on cooperative performance. Therefore, with its limitation such as a small number of samples this study contributes to the body of knowledge by providing empirical evidence on how governance variable influences positively for cooperative performance in the lack of study on the issues of good governance for cooperatives.
\end{abstract}

Keywords: transparency, accountability, responsibility, independence, fairness, cooperative performance

\section{Introduction}

The Indonesian Institute for Corporate Governance (IICG) defines corporate governance (hereafter $\mathrm{CG}$ ) as a series of mechanisms to direct and control business so it runs in accordance with the stakeholders' expectations. Therefore, it will be giving a better guarantee on the utilization of organizational resources effectively and efficiently where ultimately the business is able to achieve its goals and objectives.

The basic concept of good governance comes from big business to reduce the agency problem between managers and shareholders (Suyono, 2016; Suyono \& Farooque, 2018). However, it becomes applicable for small and medium business enterprises including cooperatives to implement good governance. Therefore, the implementation of good governance for cooperative is expected as a mechanism to create a healthy, transparent, accountable, independent, and fair responsible organization that refers to the values and principles of the cooperative.

Cooperative is one of the pillars of the Indonesian economy, therefore its existence is very crucial to support the populist economic system as mandated by the 1945 Constitution (Suyono et al., 2016; Riswan et al., 2017). However, the fact shows that many cooperatives in Indonesia are not in good condition as expected where some of those already bankrupt (Riswan et al., 2017). It is supported by the database from DINAKERKOPTRANS Banyumas with regard to the cooperatives and SMEs in Banyumas where from 512 registered cooperatives only 400 cooperatives are active. Moreover, from those 400 active cooperatives 13 cooperatives were declared healthy, 38 cooperatives were healthy enough, and 2 cooperatives were not healthy.

This condition needs more attention from all stakeholders to overcome the problem of cooperative performance where one of which by implementing good governance for cooperatives. This idea is in line with the policy of the State Ministry of Cooperatives 
and Small and Medium Enterprises where they want to create cooperative to be more professional in their business management (Riswan et al., 2017).

The implementation of governance that is not carried out properly can cause a weak internal control system which triggers the utilization of cooperative resources for personal gain, as in some corruption cases in cooperatives. Moreover, the quality of human resources also needs to be improved by involving all related parties so that the cooperative's financial performance is also expected to be better.

Huang et al. (2015) found that CG with gender proxy and member participation negatively affected cooperative performance in Malaysia, which is proxied by ROA and ROE. Meanwhile, Chibanda et al. (2009) found that institutional and governance affect the performance of 10 smallholder agricultural cooperatives in KwaZulu-Natal, South Africa. Institutional problems arise from the low level of equity and debt capital, the lack of government funding, the low level of investment, and the loss of membership. Governance problems are related to secret ballots, low levels of education, lack of production and management skills training, weak marketing arrangements, and low members contribution. Dayanandan (2013) assessed the impact of the practice of the presence of the pillars of governance such as accountability, participation, transparency, predictability and the rule of law on cooperatives show that four predictor variables such as participation, accountability, transparency and the rule of law have a significant influence on cooperative performance.

Mwanja et al. (2014) tested the effect of corporate governance on the performance of SACCOs where is measured by accountability, transparency, shareholder involvement, policies and guidelines, and awards and incentives. SACCOs performance is characterized by capital/deposit growth, membership growth, turnover growth, and customer satisfaction. The results showed that corporate governance had a significant positive impact on the performance of SACCOs.

Puspitasari dan Ludigdo (2014) revealed that the transparency principle has been implemented well where the Kopwan SU "Setia Budi Wanita" of East Java tried to provide information for employees and members transparently. The existing policies in the organization have been well conveyed to each employee and member. Moreover, the decision-making process is in accordance with standard operating procedures (SOP). In terms of audit, the cooperative has conducted audits both internally and externally. However, in terms of company structure there are still concurrent positions, namely personnel positions which have been the responsibility of the secretary and have been decided jointly by all management. Although it does not significantly influence the continuity of the cooperative business, the formation of personnel staff is still needed if the cooperative will expand business units. The principle of responsibility has also been carried out quite well where the responsibility of Kopwan SU "Setia Budi Wanita" East Java to the community through the SBW Cares program. The principle of independence in the organization has been implemented well, where there is no intervention from internal parties, namely families or shareholders who want to influence the management of the organization on the basis of their own desires.

Although cooperatives are legal entities whose primary purpose is to provide services to their members and to prosper members in particular and society in general, cooperatives must also pay attention to managing their financial management in their ability to make a profit. Profit in a cooperative is called the difference in operating results (Sisa Hasil Usaha/SHU). Judging from the concept of cooperatives, the profit function for cooperatives depends on the size of participation or transactions by 
members. The higher the participation of members, the greater the benefits received by them.

This study wants to analyze the ability of cooperatives with total assets owned to obtain SHU (profit), therefore it uses Return on Assets (ROA) as a proxy for cooperative performance. Therefore based on the above arguments, this study formulates the problems below:

(1) Whether transparency has a positive influence on cooperative performance?

(2) Whether accountability has a positive influence on cooperative performance?

(3) Whether responsibility has a positive influence on cooperative performance?

(4) Whether independence has a positive influence on cooperative performance?

(5) Whether fairness has a positive influence on cooperative performance?

\section{Theoretical Framework and Hypotheses Development}

\subsection{Theoretical Framework}

Good governance (CG), a concept based on agency theory (Jensen \& Meckling, 1976), is expected to be a useful tool to provide investors with confidence that they will receive a return from their investment. CG is closely related to how to make investors confident that managers will benefit them, managers will not steal, embezzle or invest in unprofitable projects related to funds/capital that has been invested by investors (Suyono \& Farooque, 2018).

The structure of governance in cooperatives can be seen from the presence of organizational instruments consisting of meetings of members, management, and supervisors. Meeting of members is the highest authority in the cooperative where it has the right to give tasks to the managers and supervisors. Therefore, the principles of good governance in cooperatives must be implemented to reduce agency costs.

Cooperative Law number 25/1992 closes the opportunity for management to come from non-members, meaning that the management board can only be occupied by the members (see article 29 paragraph 1). Moreover, members are the owners of the cooperative. Therefore, the agency relationship in a cooperative based on this law will be different from the basic concept or agency relationship in a big business where there is a problem between managers and owners. Meanwhile for cooperative, managers come from members, and at the same time they are the owners. However, the issuance, enables that the cooperative's managers (agents) are allowable if they are not cooperative' members who come from professional in order to manage the cooperative professionally. The appointment of non-members' managers is expected to be more effective in the implementation of good corporate governance in cooperatives.

Meanwhile from the theory of stewardship perspective, executives within the company as a waitress (Stewardess) can be motivated to act in the best way for their principal (Donaldson and Davis, 1997). Furthermore Chinn (2000) explained that stewardship theory is built on philosophical assumptions about human nature namely that humans are essentially trustworthy, able to act responsibly, have integrity and honesty towards other parties. This is what is implied in the fiduciary relationship that the shareholders want. In other words, stewardship theory views management as trustworthy to act in the best way for the public interest in general and shareholders in particular. Based on this theory the two groups namely principal and steward work together to improve welfare as they wish. Principals recruit employees based on their ability to mobilize organizational resources to maximize stakeholder benefits. In this case good corporate governance is expected to be able to foster a spirit of stewards 
in accordance with its functions for the benefit of the organization rather than only the interests of individuals.

The term corporate governance was first introduced by the Cadbury Committee in 1992 in a report known as the Cadbury report (Suyono and Farooque, 2018). From the above understanding it can be seen that in good corporate governance, there are several important things, namely:

1) Effectiveness comes from the company culture, values ethics, systems, business processes, policies and organizational structures of the company that aims to support and encourage the development of company resources and risk management more effectively and efficiently, and corporate responsibility to shareholders and other stakeholders.

2) The set of principles, policies and management systems of the company that are applied for the realization of company operations that are efficient, effective and profitable in running the organization to achieve strategic goals that meet the principles of good business practices and their application in accordance with applicable regulations, care about the environment and is based on high socio-cultural values.

3) Set of regulations stems that lead to control of the company for the creation of value for the stakeholders and for the company itself.

In accordance with the NCG there are five principles of GCG, namely transparency, accountability, responsibility, independence and fairness. Meanwhile, the implementation of good governance for cooperatives paid off adequately with the benefits and results achieved, even though the Ministry of Cooperatives and Small and Medium Enterprises has not formalized good governance in cooperatives, but has conducted socialization through the mass media and local government channels. follows;

The benefits of applying good corporate governance in more detail are described as

1) Increasing the value of the organization, for cooperatives means the value of cooperatives, especially the interests and protection of shareholders (cooperative members as cooperative owners), so that the trust and credibility of the cooperative is built in the eyes of members, partners, and other stakeholders;

2) Organizational resources, for cooperatives, means that cooperative resources, among others, are properly utilized, on target, on time, on the right size, minimizing waste and irregularities so as to realize organizational efficiency and effectiveness;

3) Organs of the organization, for cooperatives means that the organizational apparatus of member meetings, management and supervisors function optimally, enabling improvement in the performance of cooperative organization tools, appropriate risk management, so as to achieve optimal performance according to performance standards, meeting members, management and supervisors, which are determined in the internal rules of cooperatives.

Implementation of good corporate governance incooperative requires commitment, process and time, and cannot be done suddenly, or as a form of "momentary reaction" because there are certain events. However, changes to good governance paid off adequately with the benefits and results achieved. Cooperative organizations are 
managed in a healthy manner, so as to create efficiency and effectiveness, to achieve goals in the short and long term (Prijambodo, 2012).

The implementation of good corporate governance in cooperatives is carried out by restructuring the elements of the cooperative organization, in accordance with the rules and criteria of good corporate governance. Decision-makers in the cooperative (management, supervisors, members plus managers), are required to be ready to make changes, with the following strategic issues;

1) Commitment

The front line in implementing good corporate governance in cooperatives is the commitment of the decision-makers in the cooperative. Commitment and willingness of management, supervisors, members (representatives) of members to organize the organization, so that the management of cooperatives takes place on the basis of the system, and not people.

2) Cooperative management on a system basis, not a person.

The practical implications of good corporate governance in cooperatives are reflected in the management of cooperative organizations on the basis of the system, not people. Readiness, completeness of rules, mechanisms in the internal organization of cooperatives create a condition that allows the organizational machine to run following the system that was formed. Herein lies the key to good corporate governance in the cooperative, as an effort and instrument to organize the organization to be able to be managed on a system. The cooperative reforms aspects of the organization, internal rules and regulations, mechanisms and ways of working, competence, discipline, and other elements so as to ensure the realization of the 5 principles of good governance.

3) The need for improving the quality of contents on cooperative's rules

For the implementation of the principles of transparency, accountability, responsibility, independence, and fairness realized because of the complete internal rules and regulations of the cooperative that contain details of the tasks, authority, work mechanism, performance indicators, performance measurements of each cooperative organs, namely meeting members, management, supervisors and members do have competence.

4) Enforcement and compliance with legislation

Regularity, order as a pillar guarantees the management of cooperative organizations on a system basis, requiring compliance with applicable laws and regulations, including cooperative internal regulations. It becomes a standard criterion, that cooperatives, in this case the management, supervisors, members, and other personnel in cooperatives understand the various laws and regulations that cover the lives of cooperatives in Indonesia.

5) Fulfillment of Human Resource (HR) competencies

Every organ of a cooperative organization is demanded to be able to carry out its functions and tasks well. Achieving optimal performance requires cooperative HR to meet the competency qualifications required in the position.

6) Measurement of cooperative organ performance

Elements of good corporate governance in the cooperative are equipped with performance indicators, performance standards, instruments, performance measurement mechanisms of each organ in the cooperative. Measurement, assessment of performance management in the cooperative management tasks prepared and measured with the standards and mechanisms that have been inserted in the statutes, or by-laws or special cooperative's rules. 


\subsection{Hypotheses Development}

\subsubsection{Transparency and cooperative performance}

The basic principles of good corporate governance in cooperatives are the main pillars that serve as a foothold for cooperatives in selecting and determining activities that must be carried out in implementing good corporate governance in cooperatives. Besides that, by adhering to good principles, various activities can work together to achieve the goals of good governance, which is to provide added value to cooperatives as economic entities as well as social entities to enhance cooperative performance as goals that cooperatives want to achieve in prospering its members.

The progress of a cooperative is inseparable from the cooperation of the management and members, including the supervisory body. The cooperative will develop if implemented correctly in accordance with the AD/ART that has been determined. The feasibility of a cooperative is also judged by the existence of an orderly administration and organizational order. Therefore, the cooperative management can carry out an orderly financial administration and be transparent, so that what has been decided by the cooperative management has been approved by all members. Transparency is intended as having nothing to hide. Organizational information can be accessed by competent parties, whether members, management or supervisory bodies of cooperatives, relating to, among others, information on organizational performance, financial performance, risk, and mitigation. Mwanja et al. (2014) and Dayanandan (2013) found that transparency has a positive significant influence on cooperative performance. Thus, based on the above arguments, the first hypothesis is developed as follows:

$\mathrm{H}_{1}$ : Transparency has a positive influence on cooperative performance.

\subsubsection{Accountability and cooperative performance}

An organization including cooperative is declared capable of reaching a level of accountability if the organ's organization is able to function optimally and be able to account for its tasks and functions effectively. The existence of competent human resources in each post in each organ of the organization and clear performance indicators to measure the achievement of a task will improve the performance of cooperatives. Franken and Cook (2013) found that accountability is recognized as a common source of endogenous superior performance among cooperatives. Based on these arguments, the second hypothesis is formulated below:

$\mathrm{H}_{2}$ : Accountability has a positive influence on cooperative performance.

\subsubsection{Responsibility and cooperative performance}

If cooperatives meet compliance with applicable laws and regulations, internal cooperative regulations, the principle of accountability for implementing the impact will provide long-term survival of the cooperative as reflected by the good performance of the cooperative. Puspitasari and Ludigdo (2014) found that principle responsibility runs well enough where the responsibility Kopwan SU "Setia Budi Wanita" East Java to communities through SBW Care, so that public trust in the cooperative high and cooperative performance increased. Thus, the third hypothesis is formulated as below:

$\mathrm{H}_{3}$ : Responsibility has a positive influence on cooperative performance. 


\subsubsection{Independence and cooperative performance}

If the cooperative is managed professionally, without any conflict of interest or influence from any party which is not in accordance with applicable legislation, and the principles of healthy corporate then the independence of a right to materialize. In this principle there is no domination of one party to another party, and the organization cannot be intervened by another party. Independence will be realized if there is clarity in the duties of each organ in accordance with the functions outlined so that it can achieve cooperative performance as targeted. Chibanda et al.(2009) found the lack of management training and the low number of members as investors influence the independence of the performance of small cooperatives resulting in interventions by other groups that lead to poor cooperative performance. Thus, the forth hypothesis can be formulated as follows:

$\mathrm{H}_{4}$ : Independence influence positively on cooperative performance.

\subsubsection{Fairness and cooperative performance}

Fairness is an equal treatment of cooperatives to the related parties in accordance with the particular criteria. In this case, it is emphasized that the parties concerned with the company are protected from fraud and abuse of power carried out by insiders so that management roles and responsibilities are indispensable for the sustainability of cooperative performance. Setyawan and Putri(2013) found that fairness has a positive and significant effect on LPD's financial performance in Mengwi District, Badung Regency. Thus, the fifth hypothesis is formulated as follows:

$\mathrm{H}_{5}$ : Fairness has a positive influence on cooperative performance.

\section{Research Methodology}

\subsection{Research Data and Methods}

This study uses primary data that were obtained from questionnaires' survey and secondary data from the cooperative financial report fiscal year 2014 which were obtained from the Ministry of Cooperatives and SMEs. The population in this study is cooperatives in Banyumas Region, Central Java Province, Indonesia. Purposive sampling is applied to the criteria as follows:

a. Cooperatives registered in the Ministry of Cooperatives and SMEs for the Banyumas Region in 2014.

b. The cooperatives are active in 2014 .

c. The cooperatives return the questionnaire correctly.

\subsection{Operational Definitions and Variable Measurement}

1) The dependent variable in this study is cooperative performance which is proxied by Return on Assets (ROA).

2) The independent variables in this study are the principles of good corporate governance in co-operative that affect cooperative performance, namely:

a) Transparency. To maintain objectivity in doing business, the organization must provide material and relevant information in a way that is easily accessible and understood by stakeholders.

b) Accountability, the organization must be accountable for performance in a transparent and fairways.

c) Responsibility. Corporate liability is conformity (obedient) in the management of the organization to healthy corporate principles as well as applicable laws and regulations. 
d) Independence. To expedite the implementation of GCG principles, the organization must be managed independently so that each organ of the organization does not dominate each other and cannot be intervened by other parties.

e) Fairness. In carrying out its activities, the organization must always pay attention to the interests of shareholders, other stakeholders, and everyone involved based on the principle of equality and fairness.

\subsection{Data Analysis}

\section{Test of Instruments}

a. Validity test

Validity testing uses the Karl Pearson Product Moment method. With a significance level of $95 \%(\alpha=0.05)$, the test criteria:

If the value of $r_{\text {count }}>r_{\text {table }}$, it means that the question item is valid.

If the value of $r_{\text {count }} \leq r_{\text {table }}$, it means that the question item is invalid.

b. Reliability test

This test is carried out to measure the consistency of the instruments to be used and to find out that the questionnaire that has been distributed to the respondents is really reliable or not. The technique used in this test Cronbach Alpha. Reliability testing is also carried out to show the extent to which the measurement can give results that are relatively unchanged if done again on the same object.

With degrees of freedom $(\mathrm{df})=(\mathrm{n}-2)$ and $\alpha=0.05$ then:

If: $r_{\text {count }}>r_{\text {table }}$ then the statement is declared reliable

$r_{\text {count }} \leq r_{\text {table }}$ then the statement declared is not reliable

\section{Classic assumption test}

Before testing the hypothesis, first testing the independent variables is done by using a classic assumption test so that the research model provides the best estimation results or the Best Linear Unexpected Estimator. This can be done with the following tests:

a. Normality test. The normality test is used to find out whether in a regression model, dependent variable, independent variable, or both have normal distribution or not. This test is carried out using the Kolmogorov-Smirnov which could be seen from the asymptotic significant value (onetailed) $>$ alpha $(\alpha=0.05)$, then the data are normally distributed.

b. Multicollinearity Test

To test whether the regression model found a correlation among the independent variables. Multicollinearity can be detected by observing the variance inflation factor (VIF), where:

1) $\mathrm{VIF} \geq 10$ and $r \leq 0.1$ means there are multicollinearity problem.

2) VIF $<10$ and $r>0.1$ means there are no multicollinearity problem.

c. Heteroscedasticity Test

Heteroscedasticity is a condition where each confounding error has a different variance. This test is carried out to test whether the variance of confounding errors is not constant for all independent variables. The test used is the Park Gleyser method with the criteria below:

If the Sig.t value $>\alpha$ then heteroscedasticity does not occur

If the Sig.t value is $\leq \alpha$, heteroscedasticity occurs 


\section{Multiple Linear Regression Analysis}

To test the proposed hypotheses. OLS regression is used with the equation as follows:

$$
\mathrm{CP}=\beta_{0}+\beta_{1} \text { TRANS }+\beta_{2} \mathrm{ACC}+\beta_{3} \mathrm{RESP}+\beta_{4} \mathrm{IND}+\beta_{5} \mathrm{FAIR}+\varepsilon
$$

Where:

$\mathrm{CP} \quad=$ Cooperative

Performance

$\beta_{0} \quad=$ a constant

$\beta_{1}-\beta_{5}=$ Regression coefficient

TRANS = Tranparancy

ACC = Accountability

RESP $=$ Resposibility

IND = Independence

FAIR $=$ Fairness

e $\quad=$ Error

\section{Results and Discussion}

\subsection{Description of The Sample}

The data was obtained through questionnaires survey which was conducted during August 7-13, 2015. By using purposive sampling method, the process of determining the sample as in Table 1 below:

Table 1. Research Sample Determination Process

\begin{tabular}{|c|c|}
\hline Criteria & $\begin{array}{l}\text { Number of } \\
\text { Samples }\end{array}$ \\
\hline $\begin{array}{l}\text { a. Cooperatives registered in the Department of } \\
\text { Cooperatives of MSMEs and Trade throughout } \\
\text { Banyumas Regency in 2014. }\end{array}$ & 512 \\
\hline $\begin{array}{l}\text { b. Cooperatives that were not examined by Dinkop closed } \\
\text { the } 2014 \text { fiscal year }\end{array}$ & ( 347 ) \\
\hline $\begin{array}{l}\text { c. The cooperative did not return the questionnaire } \\
\text { correctly }\end{array}$ & (21) \\
\hline Number of Samples & 32 \\
\hline
\end{tabular}

\subsection{Data Analysis Results}

\section{Validity test}

The results of the questionnaire validity test can be seen in table 2 below.

Table 2 . Validity Test

\begin{tabular}{cccc} 
Item & $r_{\text {coum }}$ & $\begin{array}{c}r_{\text {table }} \\
(95 \% \text { Trust Rate })\end{array}$ & Information \\
\hline \hline TRANS & 0,737 & .349 & Valid \\
ACC & 0,735 & .349 & Valid \\
RESP & 0,791 & .349 & Valid \\
IND & 0,725 & .349 & Valid \\
FAIR & 0,770 & .349 & Valid
\end{tabular}




\section{Reliability test}

The results of questionnaire reliability testing can be seen in Table 3 below:

Table 3 . Reliability Test

\begin{tabular}{cccl} 
V a r & $\begin{array}{c}\text { Koef. Reliability } \\
(\text { r. tot })\end{array}$ & $\begin{array}{c}\boldsymbol{a} . r_{\text {table }} \\
(\text { Level of Trust } \\
95 \%)\end{array}$ & Information \\
\hline \hline TRANS & 0,737 & .349 & Reliable \\
ACC & 0,713 & .349 & Reliable \\
RESP & 0,727 & .349 & Reliable \\
IND & 0,717 & .349 & Reliable \\
FAIR & 0.726 & .349 & Reliable \\
& & & \\
\hline
\end{tabular}

\section{Descriptive Analysis}

Table 4. Average Respondent Answer Scores

\begin{tabular}{rrrrr}
\hline Variable & & Average & Mode & Information \\
\hline \hline TRANS & 3,72 & 4 & Agree \\
ACC & 3.64 & 4 & Agree \\
RESP & 3.77 & 4 & Agree \\
IND & 3.89 & 4 & Agree \\
FAIR & 3.84 & 4 & Agree \\
\hline
\end{tabular}

Table 4 above shows that the application of information disclosure (transparency ) in each Cooperative in Banyumas is adequate. This can be seen by the average score of respondents' answers which is quite high (3.72). Item variable accountability has an average of 3.64. It shows accountability are good. While the average score of the answers to the items responsibility is also quite high (3.77). It shows good responsibility which is shown by cooperative compliance with applicable regulations. For the item variable independence has an average of 3.89. The high average value indicates that the cooperative has been running independently without any intervention or dominance from any party. When the division of tasks in accordance with the duties of each person in the cooperative will help improve the performance of the cooperative. For items fairness has an average of 3.84 which shows that the equality of treatment of each member is in accordance with the portion and authority of each.

\section{Classic assumption test}

Normality. The asymp value. sig . (1-tailed) for the unstandardized variable of 0,741 is greater than the value of $\alpha \square$ which is 0.05 , so that the data used are normally distributed.

Multicollinearity. VIF of TRANS, ACC, RESP, IND, and FAIR are 2.769, 2.855, $1.605,1.892$, and 1.662 respectively which are smaller than 10 . Therefore, it can be concluded that there is no multicollinearity problem on the model.

Heteroskedasticity. By using the test Park Gleyser, the significance value of TRANS, ACC, RESP, IND, and FAIR are 0.513, $0.354,0.319,0.852$ and 0.604 respectively which are greater than the $\alpha(0.05)$. Based on this evidence, it can be concluded that there is no heteroscedasticity problem in the model. 


\subsection{The Rezults from OLS Regression}

Table 5. Summary of OLS Regression

\begin{tabular}{ccrrrr}
\hline No. & Variable & $\begin{array}{r}\text { Regression } \\
\text { Coefficient }\end{array}$ & $\mathbf{t}_{\text {coumt }}$ & $\mathbf{t}_{\text {table }}$ & Sig \\
\hline 1 & TRANS & 0.010 & 1,739 & 1,703 & 0.047 \\
2 & ACC & 0.011 & 2,475 & 1,703 & 0.010 \\
3 & RESP & 0.008 & 2008 & 1,703 & 0.027 \\
4 & IND & 0.008 & 1,844 & 1,703 & 0.038 \\
5 & FAIR & 0.005 & 1,845 & 1,703 & 0.038 \\
\hline Constant & $=-0,583$ & & & & \\
Adj R $^{2}$ & $=0.820$ & & & & \\
$\mathrm{~F}_{\text {aritumetic }}$ & $=29.314$ & & & & \\
\hline
\end{tabular}
follows:

Based on Table 5 above, multiple linear regression equations can be made as

$$
\begin{aligned}
& \mathrm{CP}=-0,583+0.010 \mathrm{TRANS}+0.011 \mathrm{ACC}_{2}+0.008 \mathrm{RESP}+0.008 \mathrm{IND}+ \\
& \mathrm{FAIR}+\varepsilon
\end{aligned}
$$

Table 5 above shows that TRANS has a significance value of 0.047 which is lower than 0.005 . This shows that the first hypothesis stating that transparency has a positive effect on cooperative performance is supported. ACC has a significant value of 0.010 which is smaller than $=0.05$. It means that the second hypothesis which states accountability has a positive effect on the performance of cooperatives is accepted. RESP has a significant value of 0 .which is smaller than 0.05 . This shows that the third hypothesis which states responsibility has a positive effect on the performance of cooperatives is accepted. IND has a significance value of 0.038 which is smaller than 0.05. This shows that the fourth hypothesis which states that independence has a positive effect on cooperative performance is accepted. FAIR has a significant value of 0.038 which is smaller than 0.05 . This shows that the fourth hypothesis which states fairness has a positive effect on cooperative performance is accepted.

\subsection{Discussion}

The finding shows that the first hypothesis stating that transparency) has a positive effect on the cooperative performance is supported. It supports the concept of agency theory stating that the information openness run by the board and the supervisory cooperative will influence positively on its performance. When the cooperative is able to implement the value of openness, solidarity, honesty, discipline, responsibility, and quality together so there are no agency fees due to any deviation. This finding is in line with Puspitasari and Ludigdo (2014) where the principle of transparency has been run well in Kopwan SU "Setia Budi Women" with providing information to employees and members in a transparent manner, although still in accordance with the ethical. Setyawan and Putri (2013) the principle of transparency affects the financial performance of LPDs in Mengwi sub-district. Cooperatives are expected to implement a joint responsibility system as a value system. The values carried are the values of openness, togetherness, honesty, discipline, responsibility, and quality of togetherness. In determining policies, cooperatives also have a policy-setting organizational tool that 
is carried out by administrators, supervisors, employees, and members. This process is expected between the management and members to know how the cooperative management mechanism can work, and be understood and carried out together. Directional communication in each part of the organizational structure will facilitate the entry of information that is timely, adequate, clear, accurate, and comparable and can be accessed by stakeholders who are commensurate with their rights. Intense coordination between all devices and apparatus is an important tool in the delivery of relevant information. When the value is understood, then implementatively people can do it, only after all this has been mastered is practiced in a system that is built so that assets become safe and cooperative performance is maintained.

For the second hypothesis in which accountability has a positive effect on cooperative performance. It is in-line with Mwanja et al. (2014) who found that the performance of SACCOs operationalized with full accountability resulting in the growth of turnover and membership. Dayanandan (2013) examined the same thing, based on the logistic regression model showing that accountability significantly affected cooperative performance. It can be explained through the duties as and authority of administrators, supervisors, and work units all included in the organizational structure that has AD/ART, while for employees in each department has written SOPs and standard also refers to the Law No. 13 of 2003 concerning employment where cooperatives pay attention to the rights and obligations that all employees are also listed in the company regulation. With accountability it is hoped that cooperative management can be responsible for each activity of the members. In line with the theory of stewardship, the management of cooperatives has a high sense of responsibility to increase profits for cooperatives. Likewise with agency theory that can be applied in cooperatives where the management and supervisors included in the structure have a written SOP so as to avoid the interests of agents. This has been done by some cooperatives in Banyumas with clear records and bookkeeping of all cooperative activities so as to assist the sustainability of cooperative performance.

The third hypothesis, responsibility has a positive effect on the performance of cooperatives. In agency theory, members have the right to give tasks to the management and supervisors in the cooperative. Instead the management and supervisor of the cooperative are responsible for delivering their accountability reports to the members' meeting. Therefore, with good reciprocity when the management and supervisor of the cooperative have completed their obligations, they will get insurance rights such as health insurance, accident insurance, then get a minimum THR of 1x salary and also get SHU every year. All are adjusted based on work focus and composition of employee positions and also employee education. This is expected to make employees have high integrity in carrying out tasks in accordance with job descriptions and applicable regulations. Based on Setyawan and Putri (2013), LPD financial performance in Mengwi District in Badung Regency is influenced by responsibility. Likewise with Puspitasari and Ludigdo (2014), responsibility is one indicator that has been carried out in the Kopwan SU "Setia Budi Wanita" East Java. A high sense of ownership of every employee, a comfortable working atmosphere, a family, a close friendship, and staying compact in dealing with every problem by carrying out a work evaluation at the beginning of each month can improve the performance of cooperatives in Banyumas.

The fourth hypothesis, independence has a positive effect on cooperative performance. In line with Puspitasari and Ludigdo (2014), there are no interventions from internal parties, namely families and or shareholders who want to influence organizational management on the basis of their own desires that affect cooperative 
performance. Based on agent theory, cooperative management does not feel intervened by other parties that will benefit it personally but enlarges partnerships with appreciation such as with government agencies and also related banking partners and also with other financial institutions. So that the collaboration between these partnerships will increasingly introduce cooperative operations in Banyumas and also provide wider access to government agencies and other related parties.

The fifth hypothesis, fairness has a positive effect on the performance of cooperatives. In realizing fairness in one of the principles of good governance in employees, suggestions, and criticisms are always delivered when employees every month for the progress of the cooperative. This is in line with the agency theory in which the principal (investor) assesses whether the agent (management) has managed the investment fund appropriately without any interests affecting it. The results from Odera (2012) also support this finding where fairness helps ensure good governance that can improve performance. Similarly, Setyawan and Putri (2013) state that fairness has a positive effect on the financial performance of the LPD in Mengwi Diversity in Badung Regency. For the sake of the implementation of good governance, not only fairness in conveying the aspirations of both members and employees, but the cooperative is able to move in the long run, providing benefits to members as shareholders in the form of services and SHU. Satisfactory services also require the formation of patterns of relationships between organs within the cooperative, between management, supervisors, members, and other organs so as to carry out clear and optimal tasks and functions.

Cooperatives are expected to refer to the single diversity, meaning that it starts from the elements of the management, supervisors, employees, members, the reception is not distinguished from background, culture, religion, or skin color, and so forth. Cooperative is a movement where members from various backgrounds, ranging from housewives, private employees, or government employees or educators, are all well received. The cooperative does not distinguish between things that affect the institution but instead enrich the existing colors so that group dynamics and membership dynamics are better and better cooperative deliver.

\section{Conclusion}

Transparency has a positive effect on the performance of cooperatives. The progress of a cooperative is inseparable from the cooperation of the management and members, including the supervisory body. The cooperative will develop if implemented correctly in accordance with the AD/ART that has been determined. The feasibility of a cooperative is also judged by the existence of an orderly administration and organizational order. The cooperative management can carry out an orderly financial administration and be transparent so that what has been decided by the cooperative management has been approved by all members. Transparency is intended as having nothing to hide. Organizational information can be accessed by competent parties, whether members, the management or supervisory bodies of cooperatives, relating to, among others, information on organizational performance, financial performance, risk, and mitigation.

Accountability has a positive effect on the performance of cooperatives. Cooperatives are able to achieve a level of accountability if organizational organs are able to function optimally and are able to account for their duties and functions effectively. The existence of competent human resources in each post in each organ of the organization, and there are clear performance measures to measure the achievement of a task will improve the performance of cooperatives. Clarity of functions, 
implementation, and accountability of cooperative management influences cooperative performance.

Responsibility has a positive effect on the performance of cooperatives. Cooperatives have fulfilled compliance with applicable laws and regulations, cooperative internal regulations such as the articles of association/by-laws, the principle of accountability will be implemented and the impact will provide long-term survival of the cooperative as reflected by the good performance of the cooperative.

Independence has a positive effect on cooperative performance. The cooperative has been managed professionally, without any conflict of interest or influence from any party that is not in accordance with applicable laws and regulations. In this principle there is no domination of one party to another party, and the organization cannot be intervened by another party. Self-reliance has been realized with no its clarity duties of each organ in accordance with the functions outlined so as to achieve cooperative performance in accordance with the target. Fairness has a positive effect on cooperative performance. The equality of treatment of cooperatives with parties concerned in accordance with the criteria and proportions that should have been implemented. In this case, it is emphasized that the parties concerned with the company are protected from fraud and abuse of authority carried out by people in such a way that management roles and responsibilities are indispensable for the sustainability of cooperative performance.

\section{References}

Chibanda, M., Ortmann, G.F., \& Lyne, M.C. 2009. Institutional and Governance Factor Influencing The Performance of Selected Smallholder Agricultural Cooperatives in Kwazulu-Natal. Agrekon. Vol 48, No. 3, 293-306.

Chinn, R. 2000. Corporate Governance Handbook, Gee Publishing Ltd. London.

Dayanandan, R. 2013. Good Governance for Better Performance of Community Organizations - Myths and Realisties!!. Journal of Power, Politics \& Governance, Vol 1, No. 1, 10-26.

Davis, J.H., Scoorman, F.D., \& Donalson, L. 1997. Toward a Stewardship Theory of Management. Academy of Management Review, Vol. 22, No. 1, 22-47.

Franken, J.R., \& Cook, M.L. 2013. Governance and Performance of Multipurpose Cooperative. Selected paper prepared for presentation at the International Conference on Economics and Management of Network -EMNet.

Huang, C.C., Zazale, S., Othman, R., Aris, N.A., \& Ariff, S.M.M. 2015. Influence of Cooperative Members' Participation and Gender on Performance. Journal of Southeast Asian Research, 2015, 1-9.

Mwanja, B.K, Marangu, W.N., Wanjere, D.M., \& Thu, K.J. 2014. Effect of Corporate Governance on Performance of Saving and Credit Co-operative Societies in Kakamega County. European Journal of Bussines and Management, Vol. 6, No. 30, 123-136.

Odera, O. 2012. Corporate Governance Problem of Savings, Credit and Cooperative Societies. International Journal of Academic Research in Business and Social Sciences, Vol.2, No. 11, 89-203.

Prijambodo. 2012. Tata Kelola Yang Baik Pada Koperasi (Good Governance Cooperative) Satu Kebutuhan Peningkatan Kualitas SDM Koperasi. http://www.depkop.go.id.

Puspitasari, D.S., \& Ludigdo. U. 2014. Good Governance of Koperasi Wanita Serba Usaha "Setia Budi Wanita" Jawa Timur. Jurnal Ilmiah Mahasiswa FEB Unibversitas Brawijaya, 2, 1, 1-24. 
Riswan, R., Suyono, E., and Mafudi, M. 2017. Revitalization Model for Village Unit Cooperative in Indonesia. European Research Studies Journal, Vol. 20 No. 4A,102123.

Setyawan, K.M., dan Putri, I.G.A.M.A.D. 2013. Pengaruh Good Corporate Governance Terhadap Kinerja Keuangan Lembaga Perkreditan Desa Di Kecamatan Mengwi Kabupaten Badung. E-Jurnal Akuntansi Universitas Udayana, Vol. 5 No. 3, 586598.

Suyono, E. 2016. Family Controlled Firm, Governance Mechanisms and Corporate Performance: Evidence from Indonesia. Jurnal Ekonomi, Bisnis dan Akuntansi Ventura Vol. 19. N0.1, 111-124.

Suyono, E., \& Farooque, O. 2018. Do Governance Mechanisms Deter Earnings Management and Promote Corporate Social Responsibility?. Accounting Research Journal, Vol. 31 No. 3. 479-495.

Suyono, E., Farooque, O.A., \& Riswan, R. (2016), Toward a Model of Traditional Retailers and Sellers Empowerment in Improving Competitiveness Against Modern Markets in Banyumas Region, Indonesia. DLSU Business and Economics Review, 25 (2), 147-165.

Republik Indonesia, 1992. Undang-undang Nomor 25 Tahun 1992 tentang Perkoperasian.

Republik Indonesia, 2003. Undang-undang Nomor 13 Tahun 2003 tentang Ketenagakerjaan. 